\title{
Neuropsychiatric disorder with basal ganglia lesions
}

\author{
Prashant Bhatele, ${ }^{1}$ Arunmozhimaran Elavarasi (1) , ${ }^{1}$ Ajay Garg ${ }^{2}$
}

${ }^{1}$ Department of Neurology, All India Institute of Medical Sciences, New Delhi, India ${ }^{2}$ Department of Neuroimaging and Interventional Neuroradiology, All India Institute of Medical Sciences, New Delhi, India

\section{Correspondence to}

Dr Arunmozhimaran Elavarasi; arun_ela@yahoo.com

Accepted 9 December 2021

Check for updates

(c) BMJ Publishing Group Limited 2022. No commercial re-use. See rights and permissions. Published by BMJ.

\begin{tabular}{|l|}
\hline To cite: Bhatele $P_{1}$ \\
Elavarasi A, Garg A. BMJ \\
Case Rep 2022;15:e245482. \\
doi:10.1136/bcr-2021- \\
245482 \\
\hline
\end{tabular}

\section{DESCRIPTION}

A 15-year-old boy with normal birth and developmental history developed fever with a sore throat, which subsided within 5 days by over-the-counter medications. Fifteen days after the resolution of fever, he developed abrupt onset vocal and motor tics with choreiform movements of his left hand, hypersexuality and nocturnal enuresis in temporal association with group A beta-haemolytic streptococcus. Possibilities such as autoimmune encephalitis like N-methyl D-aspartate (NMDA) encephalitis, Anti phospholipid antibody (APLA) syndrome, neurosarcoidosis, Bechet syndrome, mitochondrial cytopathy, Wilson's disease, post-encephalitis sequelae, neoplastic lymphoma/glioma, and paediatric autoimmune neuropsychiatric disorder associated with streptococcal infections (PANDAS) were kept, and he was evaluated.

MRI of the brain was done (figure 1). Cerebrospinal fluid (CSF) analysis cellularity and biochemistry were normal, and the evaluation for viral, bacterial, mycobacterial and fungal encephalitis was unyielding. Serum copper studies and ceruloplasmin levels were within normal limits. The serum and CSF evaluation for autoantibodies against neuronal cell surface antigens were negative. The antinuclear antibody profile and paraneoplastic profiles were also negative. The anti-DNase B titres were elevated $682(<200)$, while the antistreptolysin O (ASO) and antibasal ganglia antibodies were negative. Echocardiography was also normal. Whole mitochondrial exome sequencing and clinical exome sequencing for chorea were unremarkable. The patient's brain imaging was repeated after 6 months of initial symptoms (figure 2).

The patient had stereotypical motor movements and was using swear words and choreiform movements of the limbs in temporal association with a group A streptococcal infection, suggested by the positive anti-DNAase B titres. He fulfilled the diagnostic criteria for PANDAS. ${ }^{1}$ It is important to note that elevated anti-DNase B titres occur in $80 \%$, while the ASO titres are elevated only in $20 \%-50 \%$ of cases. $^{2}$

Neuroimaging is usually normal in PANDAS. However, basal ganglia enlargement and hyperintensities can be seen in some cases. ${ }^{3-5}$ The MRI brain showed bilateral striatal necrosis in this patient (figure 1). Such an imaging picture could be seen in mitochondrial cytopathies, amino-acidurias, Wilson's disease and parainfectious striatal necrosis. These disorders were ruled out by genetic, metabolic and antibody testing.

The disorder is self-limiting in most cases and can have a fluctuating course in relation to recurrent streptococcal infections. Symptomatic management with antipsychotics, benzodiazepines and valproate

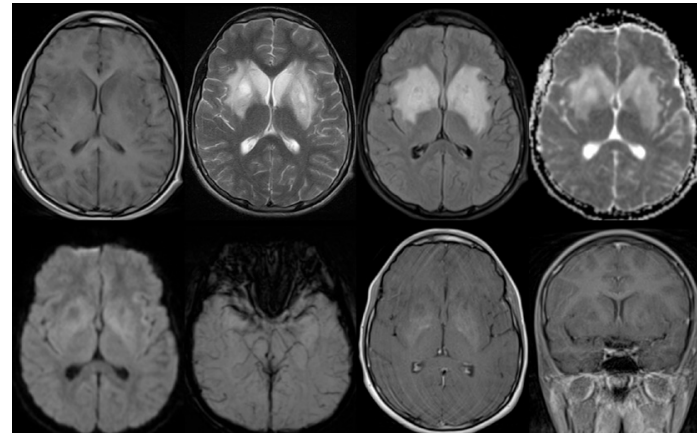

Figure 1 Bilateral symmetrical T2/FLAIR hyperintensities with swelling of bilateral basal ganglia, internal and external capsule, claustrum and extreme capsule with sparing of the insula; no diffusion restriction with minimal contrast enhancement.

might be helpful. In addition, corticosteroids, intravenous immunoglobulin and plasma exchange have been tried in case reports. In a randomised controlled study, it was found that plasma exchange led to $48 \%$ and IVIg led to $41 \%$ improvement in clinical global impression score at 1 month, as compared with placebo, which did not lead to any change in scores. ${ }^{6}$ Treatment with corticosteroids has been found to reduce symptoms by 3.5 weeks compared with those not treated who had a median duration of 11.4 weeks in observational studies in flares associated with recurrent streptococcal infections. ${ }^{7}$ Our patient was started on risperidone, sodium valproate, clonazepam and prednisolone $40 \mathrm{mg}$. He was followed up after 2 weeks. There was a complete improvement in nocturnal enuresis, $80 \%$ in sleep, $60 \%$ in urinary frequency and $30 \%$ in motor tics and hypersexuality. However, there was no improvement in vocal tics and chorea. The

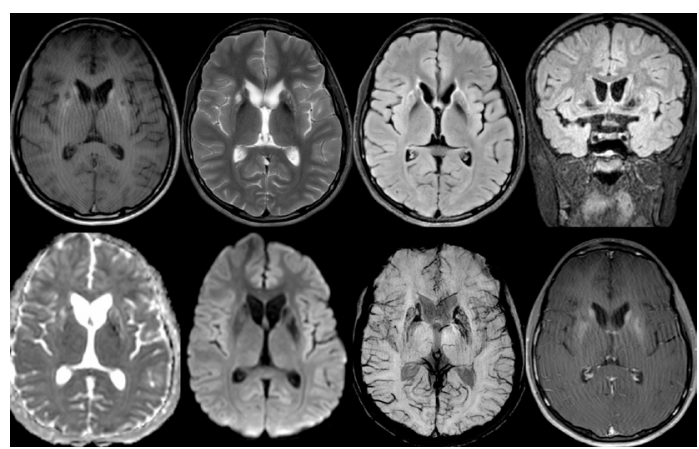

Figure 2 MRI brain 6 months later: bilateral striatal necrosis with resolution of T2/FLAIR hyperintensities of the above areas, bilateral striatal T1-hyperintensity without any enhancement. FLAIR, Fluid attenuation inversion recovery. 


\section{Learning points}

- Paediatric autoimmune neuropsychiatric disorder associated with streptococcal infection (PANDAS) is a cause of tics in children.

- Elevated anti-DNase B titres are more sensitive and occur in $80 \%$, antistreptolysin 0 titres are elevated in $20 \%-50 \%$, and antibasal ganglia antibodies in around $40 \%$.

- Neuroimaging is usually normal in PANDAS. However, rarely, basal ganglia enlargement and $\mathrm{T} 2$ hyperintensities can be seen, as in this case.

patient's caregivers chose to observe for a few weeks and decide regarding further immunotherapy later.

Contributors PB was involved in the diagnosis and management of the patient and in writing the initial draft. AE was involved in the conceptualisation of the report, diagnosis, management, and critique of the manuscript. AG was involved in the radiologic diagnosis and in critique of the manuscript.

Funding The authors have not declared a specific grant for this research from any funding agency in the public, commercial, or not-for-profit sectors.

Competing interests None declared.

Patient consent for publication Consent obtained directly from patient(s)
Provenance and peer review Not commissioned; externally peer reviewed.

Case reports provide a valuable learning resource for the scientific community and can indicate areas of interest for future research. They should not be used in isolation to guide treatment choices or public health policy.

\section{ORCID ID}

Arunmozhimaran Elavarasi http://orcid.org/0000-0002-0128-7037

\section{REFERENCES}

1 Snider LA, Swedo SE. PANDAS: current status and directions for research. Mol Psychiatry 2004;9:900-7.

2 Murphy MLet al. Prospective identification and treatment of children with PANDAS Arch Pediatr Adolesc Med 2002;156:356-61.

3 Karagulle Kendi AT, Krenzel C, Ott FW, et al. Poststreptococcal dystonia with bilateral striatal enlargement: MR imaging and spectroscopic findings. AJNR Am J Neuroradiol 2008;29:1276-8.

4 Dale RC, Church AJ, Benton S, et al. Post-streptococcal autoimmune dystonia with isolated bilateral striatal necrosis. Dev Med Child Neurol 2002:44:485-9.

5 Giedd JN, Rapoport JL, Leonard HL, et al. Case study: acute basal ganglia enlargement and obsessive-compulsive symptoms in an adolescent boy. J Am Acad Child Adolesc Psychiatry 1996;35:913-5.

6 Perlmutter SJ, Leitman SF, Garvey MA, et al. Therapeutic plasma exchange and intravenous immunoglobulin for obsessive-compulsive disorder and tic disorders in childhood. Lancet 1999;354:1153-8.

7 Sigra S, Hesselmark E, Bejerot S. Treatment of PANDAS and PANS: a systematic review. Neurosci Biobehav Rev 2018:86:51-65.

Copyright 2021 BMJ Publishing Group. All rights reserved. For permission to reuse any of this content visit

https://www.bmj.com/company/products-services/rights-and-licensing/permissions/

BMJ Case Report Fellows may re-use this article for personal use and teaching without any further permission.

Become a Fellow of BMJ Case Reports today and you can:

- Submit as many cases as you like

- Enjoy fast sympathetic peer review and rapid publication of accepted articles

- Access all the published articles

- Re-use any of the published material for personal use and teaching without further permission

Customer Service

If you have any further queries about your subscription, please contact our customer services team on +44 (0) 2071111105 or via email at support@bmj.com.

Visit casereports.bmj.com for more articles like this and to become a Fellow 